Cite this: J. Mater. Chem. A, 2013, 1, 4671

Received 17th December 2012 Accepted 14th February 2013

DOI: $10.1039 / c 3 t a 01532 g$

www.rsc.org/MaterialsA
View Article Online

View Journal / View Issue

\title{
Single-paper flexible Li-ion battery cells through a paper-making process based on nano-fibrillated cellulose
}

\author{
Simon Leijonmarck, ${ }^{* a c}$ Ann Cornell, ${ }^{\text {ac }}$ Göran Lindbergh ${ }^{\text {ac }}$ and Lars Wågberg ${ }^{\text {bc }}$ \\ Recently, a need for mechanically flexible and strong batteries has arisen to power technical solutions such \\ as active RFID tags and bendable reading devices. In this work, a method for making flexible and strong \\ battery cells, integrated into a single flexible paper structure, is presented. Nano-fibrillated cellulose \\ (NFC) is used both as electrode binder material and as separator material. The battery papers are made \\ through a paper-making type process by sequential filtration of water dispersions containing the \\ battery components. The resulting paper structure is thin, $250 \mu \mathrm{m}$, and strong with a strength at break \\ of up to 5.6 MPa when soaked in battery electrolyte. The cycling performances are good with reversible \\ capacities of $146 \mathrm{~mA} \mathrm{~h} \mathrm{~g}^{-1} \mathrm{LiFePO}_{4}$ at C/10 and $101 \mathrm{~mA} \mathrm{~h} \mathrm{~g}{ }^{-1} \mathrm{LiFePO}_{4}$ at $1 \mathrm{C}$. This corresponds to an \\ energy density of $188 \mathrm{~mW} \mathrm{~h} \mathrm{~g}^{-1}$ of full paper battery at C/10.
}

\section{Introduction}

The use of Li-ion batteries has been continuously increasing since their market introduction, both in terms of quantity and in the number of applications, now including a vast range of products such as wireless electronic devices and automobiles. ${ }^{1}$ Further applications utilizing Li-ion batteries could be reached if the batteries were to be flexible but still mechanically stable ${ }^{2}$ without the need for a protective casing. ${ }^{3}$ These markets include wearable electronic devices, ${ }^{4}$ radio-frequency identification (RFID) tags ${ }^{5,6}$ and bendable reading devices. ${ }^{7}$ Several designs of such batteries have already been produced or suggested. Two production routes can be distinguished within these presented designs. One approach comprises the production of separate components, such as the electrodes and the separator, which are later assembled. The second route, instead, creates battery cells in a single structure. Production routes of free-standing flexible separators and electrodes, later assembled into full battery structures, have been reported in a number of publications. Examples are the making of free-standing negative electrodes based on graphite using cellulose ${ }^{8}$ or micro-fibrillated cellulose $^{9}$ through an aqueous process. Another approach to free-standing electrodes, utilizing cellulose fibers as binder material, prepared graphite and $\mathrm{LiFePO}_{4}$ electrodes using an

\footnotetext{
${ }^{a}$ Department of Chemical Engineering and Technology, KTH Royal Institute of Technology, SE-100 44 Stockholm, Sweden. E-mail: simonle@kth.se; Tel: +46 8 7906557

${ }^{b}$ Department of Fibre and Polymer Technology, KTH Royal Institute of Technology, SE10044 Stockholm, Sweden

${ }^{c}$ Wallenberg Wood Science Center, KTH Royal Institute of Technology, SE-100 44 Stockholm, Sweden
}

ionic liquid-based process. ${ }^{10}$ Practically all commercial liquidtype Li-ion battery separators are bendable, including the most used polyethylene-polypropylene (PE-PP) type separator. ${ }^{11}$ However, such materials are based on non-renewable petroleum products and therefore have an unwanted environmental profile. The use of the more renewable cellulosic material in separators has been reported over a long period of time. The first use of a cellulose separator, in 1996, ${ }^{\mathbf{1 2}}$ resulted in strong papers with conductivities in the range of those of commercial PP separators. Following this, a number of cellulosic materials have been produced in Li-ion separator form. This includes fibrillated cellulose ${ }^{13}$ and cellulose/polymer composites. ${ }^{\mathbf{1 4}}$ Complete batteries assembled by such free-standing components have been reported in a few cases, such as an aqueous battery based on polymer/fibrillated cellulose composite electrodes and a filter paper separator ${ }^{15}$ with the advantage of very fast charging/discharging. However, such polymers suffer from low cycling performance, high self-discharge and low cell voltage. ${ }^{16}$ Another example is a study where all battery components were separately manufactured in a paper-making type process, using cellulose as binder and separator material. ${ }^{17}$ This process yielded mechanically strong and flexible battery components, although with low cycling performances where only half of the theoretical capacity was utilized from the first cycle.

A single structure comprising a full battery cell could be advantageous owing to a simplified assembly procedure. More importantly still, a single-structured battery would be robust since its components cannot shift position in relation to each other. This decreases the risk of short circuits during bending motions, for example. A successful attempt to produce such a battery cell was made, utilizing a commercial copy paper as a 
separator laminated together with the electrodes. ${ }^{18}$ These electrodes were made free-standing from a polyvinylidene fluoride (PVDF)/ $N$-methyl-2-pyrrolidone (NMP) slurry along with carbon nanotube (CNT) current collectors. A commercial version of a single-structured battery is being produced by Enfucell Inc. and Blue Spark Inc. These companies are producing thin and bendable batteries through a printing process on a plastic substrate. The battery chemistry is water based, with low cell voltages as a result, and is non-rechargeable.

To address the challenges described above - making flexible batteries with good mechanical properties but still maintaining acceptable cycling performance - a paper-making type of process in which nano-fibrillated cellulose (NFC) acts as binder material as well as load-bearing material could be proposed. NFC is produced by separating the fibrils of cellulosic fibers by means of mechanical force, often aided by an enzymatic treatment. This yields fibrils $5-30 \mathrm{~nm}$ wide and a few $\mu \mathrm{m}$ long $^{\mathbf{1 9 , 2 0}}$ which have promising environmental characteristics. ${ }^{21}$

Paper products from wood fibers have comparably low production cost and low environmental impact along with good mechanical properties. NFC has several advantages over the more conventional cellulose fibers, not the least regarding the nano-dimensions, allowing for incorporation in nano-structured devices. NFC has also been observed to form stronger papers ${ }^{22,23}$ which is a necessity in realizing the target properties of the current application. The use of NFC can also allow for the formation of thinner separator films since NFC fibrils are 5-30 nm wide, while cellulose fibers are $20-30 \mu \mathrm{m},{ }^{24}$ limiting how thin fiber-based separators can be made. Another reason is the size relation between NFC and the electrode particles. As many active electrode particles are in the nanometer scale, using a binder material in the nano-scale, as opposed to the micro-scale, is advantageous. This is due to the fact that a thinner binder material would be more space efficient due to a higher surface-to-volume ratio.

This paper describes a method for production of paperbased Li-ion battery cells. These cells have both electrodes and the separator integrated into a single flexible, but still mechanically strong, structure. Vacuum filtration is applied to water dispersions so as to form three-layered paper batteries (Fig. 1). No similar solution, where a single-structured battery containing all-renewable binder components, has been found in the open literature. A great advantage in using filtration for formation of multi-layered paper battery cells is the analogy to industrial papermaking. Liquid packaging board and paperboard are two examples of multi-layered cellulose or cellulose/plastic products already made on a vast industrial scale. ${ }^{25}$ These products are made through the use of high-efficiency machinery, ${ }^{26}$ where cellulose pulp is distributed on a moving de-watering belt, creating either single-layer or multilayer structures, followed by pressing and drying. In principle, the same process could be imagined for production of the batteries presented here. Such an adaptation would realize the potential for immense mass production of batteries at low production cost, resulting in flexible and mechanically strong batteries with low environmental impact.

\section{Experimental section}

\section{Production of the batteries}

The paper-based lithium-ion batteries were produced through an aqueous paper-making process. The materials used were carbon-coated lithium iron phosphate $\left(\mathrm{LiFePO}_{4}\right)$ of the type Life Power P2 supplied by Phostech Lithium, graphite of the type Timrex SLP 30 AH-354 kindly provided by Timcal Graphite \& Carbon, silicon dioxide $\left(\mathrm{SiO}_{2}\right), 99.5 \%$, particle size 5-15 nm provided by Aldrich and Super-P carbon provided by Timcal Graphite \& Carbon. The nano-fibrillated cellulose was prepared from a TEMPO-oxidized (preparation described elsewhere ${ }^{27}$ ) never-dried, dissolving pulp from Domsjö Fabriker $\mathrm{AB}$, Örnsköldsvik, Sweden. The charge density of the pulp was determined to be $600 \mu \mathrm{eq} . \mathrm{g}^{-1}$ using conductometric titration. ${ }^{28}$ Solvents used during solvent exchange were ethanol with purities of $96 \%$ and $99.5 \%$, both supplied by Solveco AB, dried acetone, SeccoSolv ( $\max 0.0075 \% \mathrm{H}_{2} \mathrm{O}$ ), supplied by Merck KGaA, and pentane, Prolabo 99.9\%, provided by VWR International. Water used for preparation of the dispersions had been purified in a Millipore system Direct-Q3.

Three aqueous dispersions were prepared - one for each electrode and one for the separator. The negative electrode dispersion consisted of $14.6 \mathrm{mg}$ NFC (dry weight), $133.4 \mathrm{mg}$ graphite and $1.9 \mathrm{mg}$ Super-P carbon in $9.5 \mathrm{~g}$ water. The mass relations were then approximately $10: 89: 1$ for NFC : graphite : Super-P carbon. The positive electrode dispersion consisted of $34.3 \mathrm{mg}$ NFC (dry weight), $241.2 \mathrm{mg} \mathrm{LiFePO}_{4}$ and $26.7 \mathrm{mg}$ Super-P carbon in $11 \mathrm{~g}$ water. The mass relations were then approximately $11: 80: 9$ for $\mathrm{NFC}: \mathrm{LiFePO}_{4}$ : Super-P carbon. The separator suspension contained $75.0 \mathrm{mg}$ NFC and $75.7 \mathrm{mg}$ $\mathrm{SiO}_{2}$ in $92 \mathrm{~g}$ water.

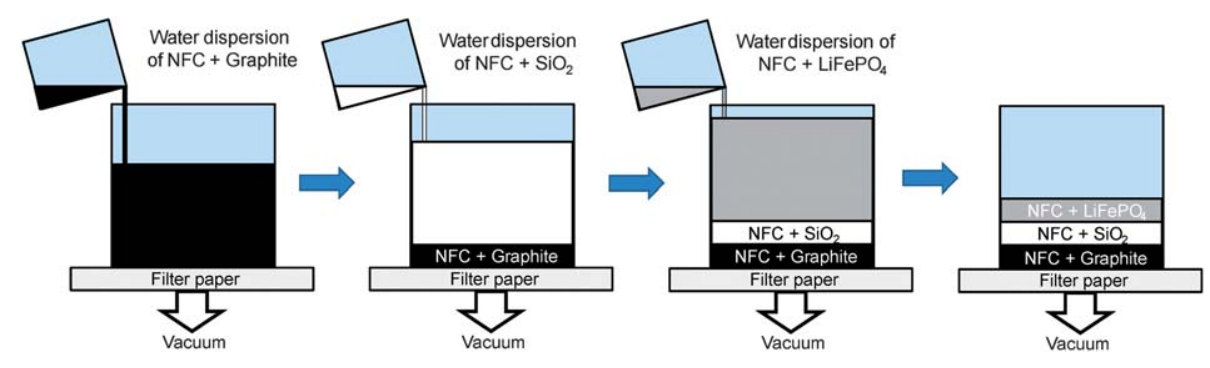

Fig. 1 An illustration of the sequential filtration steps during the production of a paper battery cell. 
Each dispersion was mixed with an Ultra Turrax DI25 Basic disperser at $8000 \mathrm{rpm}$ for 20 minutes. Thereafter, the dispersions were vacuum filtered in sequence through a Durapore membrane filter, type $0.22 \mu \mathrm{m} \mathrm{GV}$, provided by Millipore. The graphite-containing dispersion was poured first onto the filter paper. When the filtration had proceeded so that no water was visible on the filter cake surface, the $\mathrm{SiO}_{2}$-containing dispersion was poured onto the cake surface. When this filtration had also proceeded until no water was visible, the final dispersion containing $\mathrm{LiFePO}_{4}$ was added. The vacuum filtration was continued for one hour after the point in time when no water was visible on the filter cake surface. The remaining water was then solvent exchanged using the following procedure: $50 \mathrm{ml}$ each of ethanol $96 \%$, ethanol $99.5 \%$, dried acetone and pentane were added in turn and forced through the film and filter paper by the vacuum. The pentane-swollen three-layered film was removed from the filter paper and dried in vacuum at either $110{ }^{\circ} \mathrm{C}$ or $170{ }^{\circ} \mathrm{C}$. The resulting paper batteries were stored in a glove box under an argon atmosphere.

The thickness was measured using a Mitutoyo micrometer with a resolution of $1 \mu \mathrm{m}$. The porosity was estimated by dividing the volume of the constituents with the geometrical volume of the paper batteries. The densities used for this were: $\mathrm{NFC}-1.5 \mathrm{~g} \mathrm{~cm}^{-3}, \mathrm{LiFePO}_{4}-3.6 \mathrm{~g} \mathrm{~cm}^{-3}$, graphite $-2.1 \mathrm{~g} \mathrm{~cm}^{-3}$, $\mathrm{SiO}_{2}-2.6 \mathrm{~g} \mathrm{~cm}^{-3}$ and Super-P carbon $-2.0 \mathrm{~g} \mathrm{~cm}^{-3}$.

\section{SEM investigation}

The electrode materials were examined using a Hitachi S-4800 field emission SEM.

\section{Tensile testing}

Tensile testing was performed with an Instron 5944 mechanical testing system at $25{ }^{\circ} \mathrm{C}$ and $50 \% \mathrm{RH}$ using a method adapted from the ASTM D882 standard. Four to five samples of 5-7 mm wide strips of the electrode paper were stored either at $25^{\circ} \mathrm{C}$ and $50 \% \mathrm{RH}$ in air for 48 hours or at room temperature soaked in electrolyte (1 $\mathrm{M} \mathrm{LiPF}_{6}$ in EC : DEC 1: 1 by weight) for 48 hours prior to tensile testing.

\section{Electrochemical evaluation}

Battery cells were constructed as pouch cells under an argon atmosphere $\left(<1\right.$ ppm $\mathrm{H}_{2} \mathrm{O}$ and $\left.\mathrm{O}_{2}\right)$ in a glove box. The paper batteries were soaked in electrolyte $\left(1 \mathrm{M} \mathrm{LiPF}_{6}\right.$ in ethylene carbonate (EC) : diethyl carbonate (DEC) $1: 1$ by weight with an addition of $2 \mathrm{wt} \%$ vinylene carbonate (VC)) for 5 minutes under vacuum. These soaked papers $\left(2-3 \mathrm{~cm}^{2}\right)$ were then inserted between the current collectors (aluminium foil, $25 \mu \mathrm{m}$ thick, and copper foil, $25 \mu \mathrm{m}$ thick, supplied by Advent Research Materials) so that the current collectors did not overlap. The negative side of the papers was placed towards the copper and the positive side towards the aluminium. To avoid short-circuit, the current collectors did not completely cover the electrode surfaces. The outermost edges were left without direct contact with the metals. A consequence of this is that some of the theoretical capacity could be inaccessible. The battery cells were sealed in a pouch cell at $10 \mathrm{mPa}$.
The currents used during discharge are given in multiples of $\mathrm{C}$ - the current needed to charge the electrode material completely in one hour. The specific capacity used to calculate C-rate was $170 \mathrm{~mA} \mathrm{~h} \mathrm{~g}{ }^{-1} \mathrm{LiFePO}_{4}$ (as the positive electrode was limiting).

The mass of $\mathrm{LiFePO}_{4}$ was calculated by multiplying the actual mass of the paper sample by the mass ratio between $\mathrm{LiFePO}_{4}$ and the total dry mass of the paper constituents that were added into the water dispersions. This was based on the assumption that the mass relation between NFC, $\mathrm{LiFePO}_{4}$, graphite and Super-P carbon was the same in the electrode paper as it was in the initial water dispersions.

To test the electrochemical performance during bending, electric impedance spectroscopy (EIS) was carried out with a Gamry PCI4 G750 potentiostat between $300 \mathrm{kHz}$ and $0.1 \mathrm{~Hz}$ with ten measurements per decade of frequency. A paper battery, $0.5 \mathrm{~cm}$ wide and $2 \mathrm{~cm}$ long, was prepared in a pouch cell as described above. The battery was first charged/discharged for two cycles at $0.1 \mathrm{C}$, followed by charging at $0.1 \mathrm{C}$ up to $10 \%$ state of charge (SOC). EIS was then performed on this battery in both unbent and bent states. The bending was performed at two different bending radii ( 7 and $15 \mathrm{~mm}$ ), with the full length of the battery bent cylindrically, and with both electrodes in turn facing inwards.

\section{Results and discussion}

Sequential filtration was used to form three-layered paper battery cells. For this, three water dispersions were used (Fig. 1). The first, creating the negative electrode, consisted of graphite powder, Super-P carbon and NFC at dry weight ratio $89: 1: 10$. The second dispersion, forming the separator, consisted of $50: 50$ by weight of NFC and $\mathrm{SiO}_{2}$ powder. The third and final dispersion created the positive electrode and contained $\mathrm{LiFePO}_{4}$, Super-P carbon and NFC at a dry weight ratio of $80: 9: 11$ in water. The first dispersion, i.e. the negative electrode, was vacuum-filtered until no liquid water was visible on the top surface. Onto this surface, the second dispersion, containing the separator, was then added. Following water removal until this surface was also without visible water, the third and final dispersion was added. To keep the NFC structure as open as possible and to avoid creasing during drying, the remaining water was solvent exchanged by addition of, in consecutive steps, ethanol, acetone and finally pentane. After these steps, the three-layered solvent-swollen film was removed from the filter paper and dried under vacuum at $110{ }^{\circ} \mathrm{C}$ or $170{ }^{\circ} \mathrm{C}$ for 24 hours.

This method enabled full control over the active material loadings of the electrodes by controlled additions from the respective water dispersion. The loading used in this work was

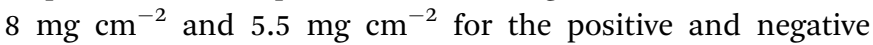
electrodes, respectively, which corresponded to $68 \mathrm{~mA} \mathrm{~h} \mathrm{~g}^{-1}$ and $82 \mathrm{~mA} \mathrm{~h} \mathrm{~g}^{-1}$ for the full paper battery. The theoretical specific capacities of $170 \mathrm{~mA} \mathrm{~h} \mathrm{~g}^{-1}\left(\mathrm{LiFePO}_{4}\right)$ and $372 \mathrm{~mA} \mathrm{~h} \mathrm{~g}$ (graphite) were used. The over-capacity of $20 \%$ for the negative electrode was chosen to avoid lithium plating on the graphite during charging of the battery. The choice of $\mathrm{LiFePO}_{4}$ and 


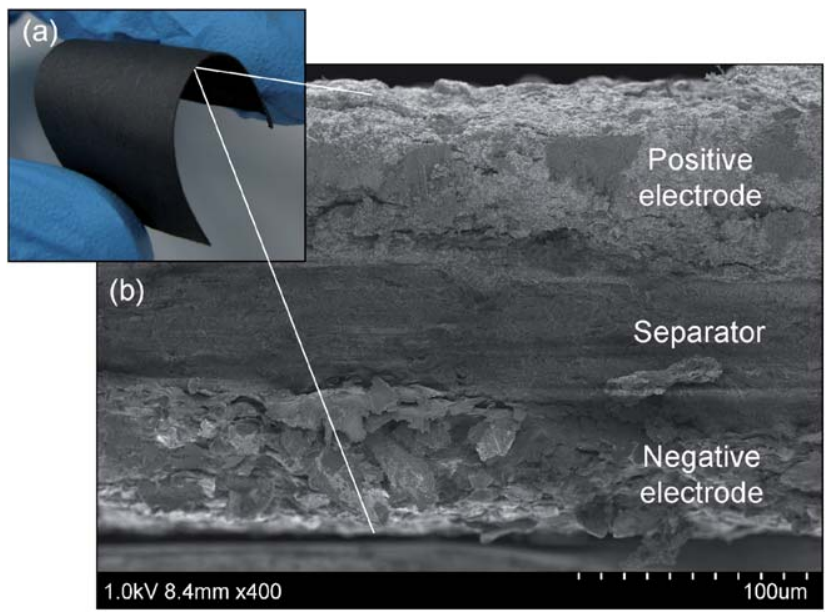

Fig. 2 (a) Photograph illustrating the flexibility of a paper battery. (b) SEM image of a paper battery cross-section.

graphite was based on the low environmental impact and relatively low material cost. This method of producing paper battery cells is in no way exclusive to these electrode materials, basically any electrode material could potentially be used.

After drying under vacuum, thin $(250 \mu \mathrm{m})$ and flexible paper batteries were formed (Fig. 2a). Scanning electron microscopy (SEM) imaging of a paper battery cross-section shows three discrete and well-adhering layers comprising the three battery components (Fig. 2b).

\section{Characterization of mechanical properties}

For evaluation of the mechanical properties of the paper batteries, tensile testing was performed. All samples had been either in air or soaked in battery electrolyte at room temperature. The former test was made for convenient comparison of the data with those of other materials, while the latter test was designed to simulate the actual conditions during battery use. The paper samples tested were dried at either $110{ }^{\circ} \mathrm{C}$ or $170{ }^{\circ} \mathrm{C}$ prior to the conditioning in air or in electrolyte. All samples were flexible with good mechanical properties (Table 1). Young's modulus and ultimate strength were in the same range, 0.19-0.26 GPa and 4.6-5.6 MPa, respectively, with the exception of the dry (stored in air) sample from $110{ }^{\circ} \mathrm{C}$ where the values were $0.39 \mathrm{GPa}$ and 9.0 $\mathrm{MPa}$. The largest differences between the measured parameters were found for the strain at break of the different samples. For the higher drying temperature, $170{ }^{\circ} \mathrm{C}$ as compared to $110{ }^{\circ} \mathrm{C}$, the strain at break was essentially halved for both dry samples $(4.1 \%$ as compared to $8.3 \%)$ and soaked samples (9.2\% as compared to $19.2 \%)$. Most likely, this originates from irreversible structural changes, such as the processes found during hornification of cellulose fibers. ${ }^{29}$ Such processes take place when water is removed from cellulosic materials, resulting in stiffer materials with reduced strength. Comparing the dry samples to the soaked, it can be seen that the paper structure became more ductile when soaked in the electrolyte, as evident from the higher strain at break.

\section{Electrochemical characterization}

Both the battery cells dried at $110{ }^{\circ} \mathrm{C}$ and $170{ }^{\circ} \mathrm{C}$ were successfully cycled at all tested C-rates. For the samples dried at $110{ }^{\circ} \mathrm{C}$, the discharge capacity was $121 \mathrm{~mA} \mathrm{~h} \mathrm{~g}^{-1}$ after 10 cycles at $\mathrm{C} / 10$. At the 10 th discharge at $1 \mathrm{C}$, the capacity was only $43 \mathrm{~mA} \mathrm{~h} \mathrm{~g}^{-1}$ (Fig. 3a). The measured capacities were in addition irregular over the cycles, especially at higher currents. Such irregularities are likely caused by parasitic side reactions with water, for example. This appears to take place at high potentials during charging and at low potentials during discharging, when the potential responses were fluctuating (Fig. 3b).

For samples dried at $170{ }^{\circ} \mathrm{C}$, the cycling properties were dramatically improved. The 10th cycle at $\mathrm{C} / 10$ (Fig. 3a) had a discharge capacity of $146 \mathrm{~mA} \mathrm{~h} \mathrm{~g}{ }^{-1} \mathrm{LiFePO}_{4}$, correlating to a total specific capacity of $58 \mathrm{~mA} \mathrm{~h} \mathrm{~g}{ }^{-1}$, a total specific energy density of $188 \mathrm{~mW} \mathrm{~h} \mathrm{~g}^{-1}$ and a total volumetric energy density of $134 \mathrm{~mW} \mathrm{~h} \mathrm{~cm}^{-3}$, whereas the 10 th cycle at $1 \mathrm{C}$ showed a capacity of $101 \mathrm{~mA} \mathrm{~h} \mathrm{~g}^{-1}$. The final, 45th, cycle performed at $\mathrm{C} / 10$ showed a capacity of $135 \mathrm{~mA} \mathrm{~h} \mathrm{~g}^{-1}$. The coulombic efficiency readings were consistent in the range $99.5-100 \%$, with the exception of the first cycles for each new $\mathrm{C}$ rate. The cycling curves for samples dried at $170{ }^{\circ} \mathrm{C}$ were much smoother than those dried at $110{ }^{\circ} \mathrm{C}$ and correlated better with cycling curves for commercial graphite/LiFePO ${ }_{4} \cdot{ }^{30}$ Likely, the irregularities in the cycling curves and the lower current efficiencies found for batteries dried at $110{ }^{\circ} \mathrm{C}$ relate to solvent residues. Drying at a higher temperature should be more efficient in removing such residues.

A potential danger with integrating electrodes and the separator in a single unit, especially when the constituents are in the form of dispersions during the manufacturing process, is short-circuiting. This might occur either by formation of an electrically conducting tunnel through the separator layer during the filtration process, or by an overlap of the two electrodes at the edges of the battery paper. To test for the occurrence of short circuits, a battery, dried at $170{ }^{\circ} \mathrm{C}$, was kept at open circuit voltage after the last, 45th, charging in the cycling scheme. The voltage remained above 3.32 V even after 150 hours

Table 1 The mechanical characteristics of the paper batteries

\begin{tabular}{|c|c|c|c|c|}
\hline & $\begin{array}{l}\text { Dried at } 110{ }^{\circ} \mathrm{C}, \\
\text { stored at } 50 \% \mathrm{RH}\end{array}$ & $\begin{array}{l}\text { Dried at } 170{ }^{\circ} \mathrm{C}, \\
\text { stored at } 50 \% \mathrm{RH}\end{array}$ & $\begin{array}{l}\text { Dried at } 110{ }^{\circ} \mathrm{C}, \\
\text { soaked in electrolyte }\end{array}$ & $\begin{array}{l}\text { Dried at } 170{ }^{\circ} \mathrm{C}, \\
\text { soaked in electrolyte }\end{array}$ \\
\hline Young's modulus [GPa] & 0.39 & 0.26 & 0.19 & 0.20 \\
\hline Ultimate strength $[\mathrm{MPa}]$ & 9.0 & 5.0 & 5.6 & 4.6 \\
\hline Strain at break $[\%]$ & 8.3 & 4.1 & 19.2 & 9.2 \\
\hline
\end{tabular}


(a)

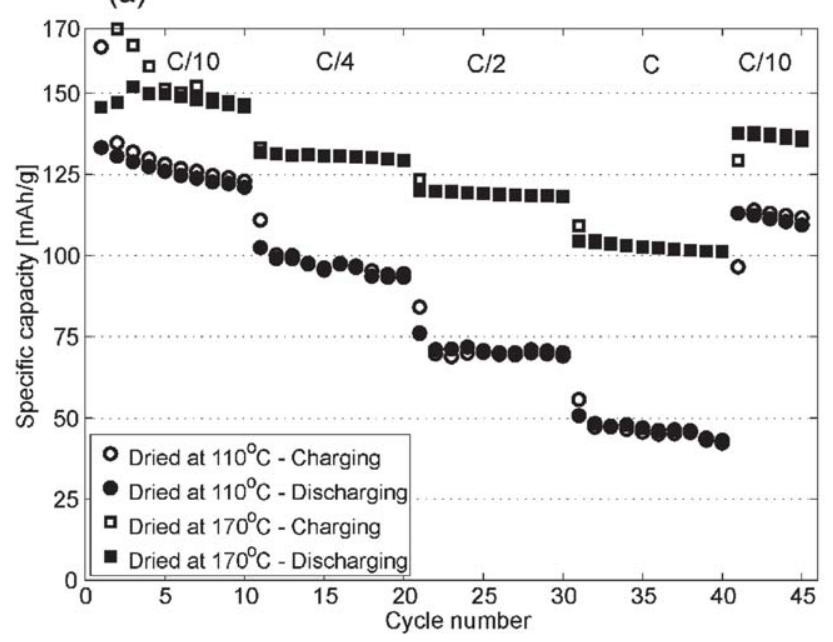

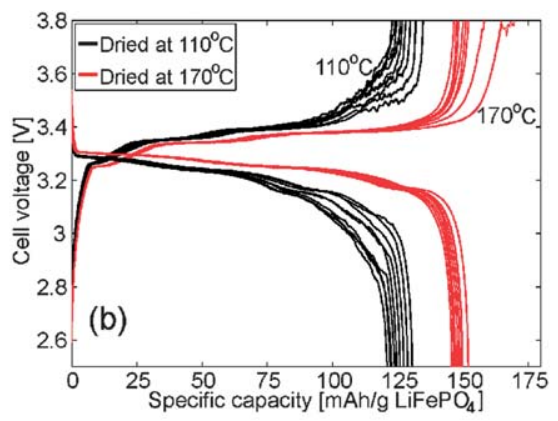

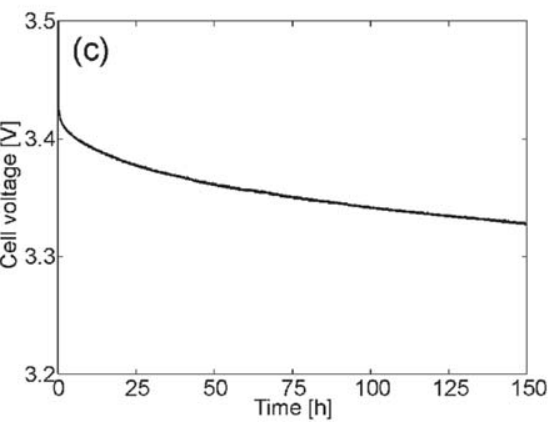

Fig. 3 Electrochemical results for paper battery cells dried at $110^{\circ} \mathrm{C}$ and $170^{\circ} \mathrm{C}$. (a) Cycling was performed at $\mathrm{C} / 10, \mathrm{C} / 4, \mathrm{C} / 2, \mathrm{C}$ and $\mathrm{C} / 10$ as indicated in the graph to test the rate capability. (b) Cycles 2-10 for both drying temperatures are shown during the initial $\mathrm{C} / 10$ cycles. (c) Open-circuit voltage for a paper battery stored at $170^{\circ} \mathrm{C}$, following the 45 th charging, at $\mathrm{C} / 10$, of the cycling procedure in (a). The very low decrease of cell voltage indicates an absence of short circuits.

(Fig. 3c), clearly displaying an absence of short circuits. In addition, full charge at $\mathrm{C} / 10$ up to the cut-off voltage at $3.8 \mathrm{~V}$ was followed by a resting period of 300 hours. After this, the battery was charged again with the same parameters. After a charge of only $1.7 \mathrm{~mA} \mathrm{~h} \mathrm{~g}^{-1}$, the cut-off voltage was once again reached. That is, a self-discharge of only $1.1 \%$ was measured over a period of 300 hours. In fact, no battery cells made during tests leading to this publication have shown signs of short circuits.

The long-term cycling properties, for samples stored at $170{ }^{\circ} \mathrm{C}$, were evaluated by another cycling procedure where the C-rate was kept constant so as to distinguish the actual capacity fade. Three cycles were performed at $\mathrm{C} / 10$ for the purpose of solid electrolyte interface (SEI) formation followed by 426 cycles at $\mathrm{C} / 2$. The measured capacities for these cycles at $\mathrm{C} / 2$

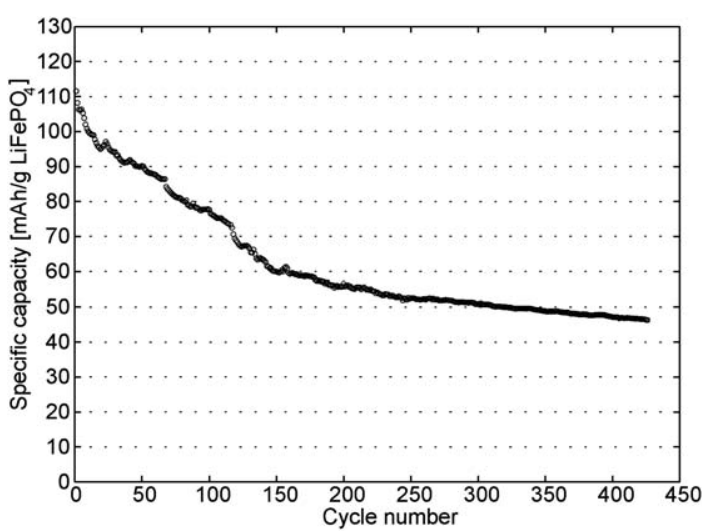

Fig. 4 Discharge capacities at $\mathrm{C} / 2$ for a paper battery cell stored at $170{ }^{\circ} \mathrm{C}-$ evaluation of the cycling stability.
(Fig. 4) were $110 \mathrm{~mA} \mathrm{~h} \mathrm{~g}^{-1}$ for the first cycle after formation, $80 \mathrm{~mA} \mathrm{~h} \mathrm{~g}^{-1}$ after 100 cycles, $57 \mathrm{~mA} \mathrm{~h} \mathrm{~g}^{-1}$ after 200 cycles and $46 \mathrm{~mA} \mathrm{~h} \mathrm{~g}^{-1}$ after the final 426 th cycle. The paper battery cells can thus be used for hundreds of cycles with a large part of the capacity remaining. The decrease of capacity is believed to originate from losses of cyclable lithium, due to parasitic side reactions with water, for example, or reformation of deteriorated SEI layers. The mean coulombic efficiency over the 426 cycles was $99.7 \%$. Accumulating this over these cycles $\left(0.997^{426}\right)$ results in a theoretical capacity loss of $72 \%$ assuming that all irreversible capacity leads to losses of cyclable lithium. The measured capacity loss up to 426 cycles was 58\%, making it plausible that side-reactions are responsible for the capacity fade. Issues with low coulombic efficiencies and capacity fade for batteries containing cellulose have been previously reported $^{18}$ where coulombic efficiencies of $94-97 \%$ were reported.

The electrochemical properties of the paper battery in bent state were important to characterize considering the imagined applications. For this, EIS was utilized at different bending radii. The resulting Nyquist plot (Fig. 5) gives information ${ }^{36,37}$ about the ionic resistance (inset of Fig. 5), charge transfer resistance (half circle peaking at $380 \mathrm{~Hz}$ ) and diffusion (tail between $0.1 \mathrm{~Hz}$ and $12 \mathrm{~Hz}$ ). Very small changes due to bending were measured for these processes. Only at the smallest bending radius measured $(7 \mathrm{~mm})$ with the positive electrode inwards, the charge transfer resistance was increased (48\%). These measurements indicate that the presented paper battery can be used as power source in flexible devices without dramatic changes in performance while bent. In addition, the ionic resistance in the liquid phase was determined to be $16 \Omega \mathrm{cm}^{2}$ (inset of Fig. 5). 


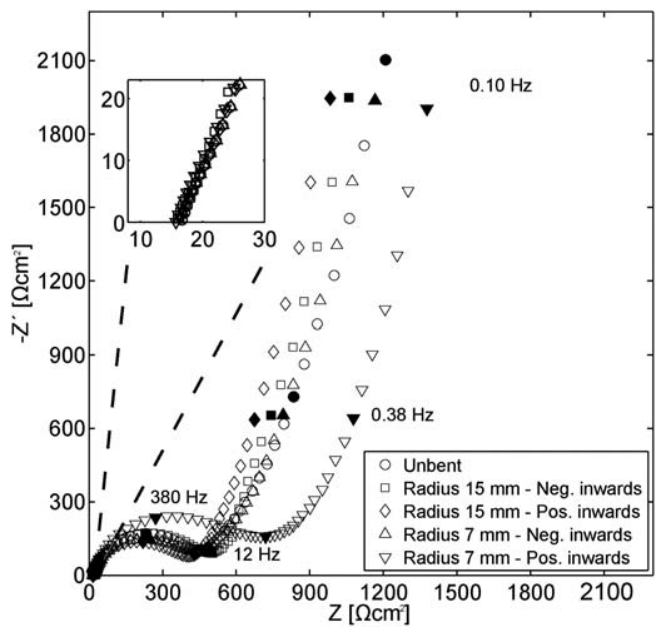

Fig. 5 EIS measurements on a paper battery charged to $10 \%$ SOC. Results for a battery in unbent state as well as for a battery bent to two different bending radii (7 and $15 \mathrm{~mm}$ ) and with both the negative and the positive electrode facing inwards. The filled markers are measured at the same frequencies, as indicated in the figure.

The results clearly show that the method presented here produces single-paper batteries with good mechanical properties as well as good performance during cycling. This method is in no way specific for the two electrode materials, graphite and $\mathrm{LiFePO}_{4}$, chosen in this study. Instead, a range of different electrode materials should be suitable. Comparing the two drying temperatures, $110{ }^{\circ} \mathrm{C}$ and $170{ }^{\circ} \mathrm{C}$, it is clear that the best mechanical and cycling properties were in disagreement. At $170{ }^{\circ} \mathrm{C}$, the capacity at higher C-rates and coulombic efficiency were superior. Conversely, the mechanical properties, with the strain at break as the most prominent, were found to be highest for samples dried at $110{ }^{\circ} \mathrm{C}$, both dry and soaked samples. However, the mechanical properties of the paper batteries dried at $170{ }^{\circ} \mathrm{C}$ were still of very good quality (Table 1 ). The strength of this battery while soaked in battery electrolyte was $4.6 \mathrm{MPa}$, at a strain of $9.2 \%$. Using the measured thickness of $250 \mu \mathrm{m}$ and assuming a width of $100 \mathrm{~mm}$, the battery paper would tolerate a load of up to $11.5 \mathrm{~kg}$ before break. This is achieved even though the battery paper consists of only $10 \%$ NFC, in total, by volume. As for the environmental aspects of the presented paper battery, it is obvious that not only is the toxic $N$-methyl-2-pyrrolidone $(\mathrm{NMP})^{31-33}$ omitted in the production process, but also all components in the battery, except the inorganic active and filler particles, are made of renewable cellulose. A drawback would be the use of pentane, which might be possible to eliminate in future studies. Looking at the economic aspects, it also looks promising. It is hard to evaluate the anticipated commercial price of NFC, but a successful adaptation into a commercial paper-making process would lead to very low production costs. Looking at the targets for this study - the making of batteries that are environmentally friendly, low cost, mechanically strong, flexible and that have good cycling performance - they are all either fulfilled or deemed very probable. Such strong batteries, that still are bendable, could be used in a wide variety of new applications in which flexibility is essential.
For further improvements of this concept of making batteries, introduction of integrated current collectors would be beneficial. This could perhaps be solved by added layers of carbon particles/NFC ${ }^{34}$ or carbon nano-tubes ${ }^{18}$ on the electrode layers. To address the decrease in specific capacity, caused by the relatively low coulombic efficiency of $99.7 \%$, over cycling, great control of the water/solvent content in the NFC must be assured. This could possibly be done in a number of ways, including high-vacuum treatment, super-critical carbon dioxide purging $^{35}$ or hydrophobation of the polar cellulose chains.

\section{Conclusions}

To summarize, a flexible, but still mechanically strong, full graphite/ $/ \mathrm{LiFePO}_{4}$ battery incorporated into a single structure has been successfully prepared. It includes the use of NFC as binder material in the electrodes as well as in the separator, and production through a simple water-based paper-making type process. The resulting battery cells are mechanically strong and flexible with good cycling properties (up to $101 \mathrm{~mA} \mathrm{~h} \mathrm{~g} \mathrm{~g}^{-1}$ $\mathrm{LiFePO}_{4}$ at $1 \mathrm{C}$ ) and are made using renewable cellulosic materials. Additionally, the paper-battery cells may be produced at low cost by using existing paper-making procedures. It opens up new application of batteries, where there is a need for a flexible or disposable energy source, such as RFID tags and flexible reading devices, as well as simple assembly of batteries, especially since the battery papers can be cut to any size with simple tools, such as scissors, without creating short circuits.

\section{Acknowledgements}

The Knut and Alice Wallenberg Foundation is much appreciated for financial support. A. Svensson is much acknowledged for the preparation of the TEMPO-oxidized NFC.

\section{Notes and references}

1 B. Scrosati, J. Solid State Electrochem., 2011, 15, 1623-1630.

2 H. Nishide and K. Oyaizu, Science, 2008, 319, 737-738.

3 Linden's Handbook of Batteries, ed. T. B. Reddy, McGraw-Hill, 2011, pp. 26.41-26.47.

4 J. A. Rogers, T. Someya and Y. G. Huang, Science, 2010, 327, 1603-1607.

5 V. Subramanian, J. M. J. Frechet, P. C. Chang, D. C. Huang, J. B. Lee, S. E. Molesa, A. R. Murphy and D. R. Redinger, Proc. IEEE, 2005, 93, 1330-1338.

6 B. T. Shao, Q. Chen, R. Liu and L. R. Zheng, Microw. Opt. Tech. Lett., 2012, 54, 226-230.

7 I. J. Chung and I. Kang, Mol. Cryst. Liq. Cryst., 2009, 507, $1-17$.

8 L. Jabbour, M. Destro, C. Gerbaldi, D. Chaussy, N. Penazzi and D. Beneventi, J. Mater. Chem., 2012, 22, 3227-3233.

9 L. Jabbour, C. Gerbaldi, D. Chaussy, E. Zeno, S. Bodoardo and D. Beneventi, J. Mater. Chem., 2010, 20, 7344-7347.

10 S. S. Jeong, N. Bockenfeld, A. Balducci, M. Winter and S. Passerini, J. Power Sources, 2012, 199, 331-335.

11 P. Arora and Z. M. Zhang, Chem. Rev., 2004, 104, 4419-4462. 
12 I. Kuribayashi, J. Power Sources, 1996, 63, 87-91.

13 S.-J. Chun, E.-S. Choi, E.-H. Lee, J. H. Kim, S.-Y. Lee and S.-Y. Lee, J. Mater. Chem., 2012, 22, 16618-16626.

14 A. Chiappone, J. R. Nair, C. Gerbaldi, L. Jabbour, R. Bongiovanni, E. Zeno, D. Beneventi and N. Penazzi, J. Power Sources, 2011, 196, 10280-10288.

15 G. Nyström, A. Razaq, M. Strømme, L. Nyholm and A. Mihranyan, Nano Lett., 2009, 9, 3635-3639.

16 L. Nyholm, G. Nyström, A. Mihranyan and M. Strømme, Adv. Mater., 2011, 23, 3751-3769.

17 L. Jabbour, M. Destro, C. Gerbaldi, D. Chaussy, N. Penazzi and D. Beneventi, Nord. Pulp Pap. Res. J., 2012, 27, 472-475.

18 L. B. Hu, H. Wu, F. La Mantia, Y. A. Yang and Y. Cui, ACS Nano, 2010, 4, 5843-5848.

19 D. Klemm, F. Kramer, S. Moritz, T. Lindström, M. Ankerfors, D. Gray and A. Dorris, Angew. Chem., Int. Ed., 2011, 50, 54385466.

20 I. Siro and D. Plackett, Cellulose, 2010, 17, 459-494.

21 L. A. Berglund and T. Peijs, MRS Bull., 2010, 35, 201-207.

22 M. Henriksson, L. A. Berglund, P. Isaksson, T. Lindström and T. Nishino, Biomacromolecules, 2008, 9, 1579-1585.

23 H. Sehaqui, A. D. Liu, Q. Zhou and L. A. Berglund, Biomacromolecules, 2010, 11, 2195-2198.

24 Mechanics of Paper Products, ed. K. Niskanen, Walter de Gruyter GmbH \& Co, Berlin/Boston, 2011, p. 239.

25 Handbook of Paper and Board, ed. H. Holik, WILEY-VCH Verlag GmbH \& Co, Weinheim, 2006, p. 13-19 \& 219-223.
26 Paper Chemistry and Technology, ed. M. Ek, G. Gellerstedt and G. Henriksson, Walter de Gruyter GmbH \& Co, Berlin, 2009.

27 T. Saito, M. Hirota, N. Tamura, S. Kimura, H. Fukuzumi, L. Heux and A. Isogai, Biomacromolecules, 2009, 10, 19921996.

28 S. Katz, R. P. Beatson and A. M. Scallan, Sven. Papperstidn., 1984, 87, R48-R53.

29 G. V. Laivins and A. M. Scallan, in Transactions of the 10th fundamental research symposium, ed. C. F. Baker, Pira International, Oxford, UK, 1993, p. 1235-1260.

30 M. Kassem, J. Bernard, R. Revel, S. Pelissier, F. Duclaud and C. Delacourt, J. Power Sources, 2012, 208, 296-305.

31 Europen Union Commission Regulations (EC) 790/2009, 2009, pp. 235/1-235/439.

32 A. M. Saillenfait, F. Gallissot, I. Langonne and J. P. Sabate, Food Chem. Toxicol., 2002, 40, 1705-1712.

33 A. M. Saillenfait, F. Gallissot and G. Morel, Food Chem. Toxicol., 2003, 41, 583-588.

34 S. Leijonmarck, A. Cornell, G. Lindbergh and L. Wågberg, Nano Energy, submitted.

35 H. Sehaqui, Q. Zhou and L. A. Berglund, Compos. Sci. Technol., 2011, 71, 1593-1599.

36 D. Aurbach, J. Power Sources, 2000, 89, 206-218.

37 C. H. Hamann, A. Hamnett and W. Vielstich, Electrochemistry, Wiley-VCH Verlag $\mathrm{GmbH} \& \mathrm{Co}$, Weinheim, 2nd edn, 2007, pp. 278-287. 